\title{
IMPLEMENTASI GOOD GOVERNANCE DI KECAMATAN GAJAH PUTIH KABUPATEN BENER MERIAH TAHUN 2020 PADA PELAYANAN PEMBUATAN AKTA JUAL BELI TANAH
}

\author{
Surahman, M. Akmal, M. Nazaruddin \\ Prodi Magister Administrasi Publik, Fakultas Ilmu Sosial dan Ilmu Politik Universitas Malikussaleh \\ Jln. Tengku Chik diTiro, NO. 26, Lancang Garam, Lhokseumawe-24351 \\ Korespondensi: e-mail: akmal@unimal ac.id
}

\begin{abstract}
Penelitian ini merujuk pada azas-azas penyelenggaraan pemerintahan yang tertuang dalam Undang-Undang Pemerintah Daerah yang menyebutkan bahwa dalam mengatur penyelenggaraan pemerintahan wajib menjalankan asas-asas umum penyelenggaraan pemerintahan diantaranya asas kepastian hukum, asas tertib penyelenggaraan pemerintahan, asas kepentingan umum, asas keterbukaan, asas proporsionalitas, asas profesionalitas, asas akuntabilitas, asas efisiensi dan efektivitas. Penelitian ini membatasi pada prinsip efektivitas dan efisiensi dalam pelayanan pembuatan Akta Jual Beli Tanah dengan mengimplementasikan prinsip tata kelola pemerintahan yang baik (good governance).Lokasi penelitian bertempat di Kecamatan Gajah Putih, Kabupaten Bener Meriah.Penelitian ini bertujuan untuk mengetahui dan menganalisis implementasi prinsip good governance pada pelayanan pembuatan AJB tanah beserta hambata internal dan eksternalnya.Metode penelitian yang digunakan adalah penelitian kualitatif dengan teknik penentuan informan menggunakan teknik purposive. Data diperoleh dengan menggunakan metode observasi, wawancara, dan dokumen.Hasil Penelitian menunjukkan bahwa implementasi penyelenggaraan pemerintahan di Kecamatan Gajah Putih khususnya pada pelayanan pembuatan AJB tanah belum berjalan sesuai dengan prinsip good governance dengan azas efektif dan efisien. Hal tersebut disebabkan oleh Camat yang baru terpilih di tahun 2020 belum memiliki izin PPAT Sementara, Tidak tersedianya printer khusus untuk mencetak AJB tanah, dan Kecamatan Gajah Putih tidak memiliki Standar Operasional Prosedur (SOP) pelayanan pembuatan AJB tanah sehingga menimbulkan indikasi pungutan liar karena tidak jelasnya biaya yang timbul atas transaksi akta dan membuat penyelesaian AJB tanah tidak tepat waktu karena tidak ada penyebutan batas hari maksimal pengerjaan AJB tanah tersebut. Hambatan internal disebabkan sumber daya manusia, sumber daya fasilitas dan SOP yang belum tersedia, sedangkan hambatan eksternal antara lain waktu pengukuran tanah mengalami hambatan karena lokasi pengukuran tanah sangat jauh, dan cenderung berada pada lokasi yang curam, sehingga menghabiskan waktu para aparatur kampung yang melakukan pengukuran tanah, Reje tidak berada di Kampung dan indikasi merubah ukuran tanah untuk menurunkan biaya yang timbul dari harga transaksi tanah pada pembuatan AJB tanah.

Keywords: Implementasi, Good Governance, Akta Jual Beli Tanah
\end{abstract}

\section{Pendahuluan}

Kecamatan sebagai perangkat daerah juga mempunyai kekhususan dibandingkan dengan perangkat daerah lainnya dalam pelaksanaan tugas pokok dan fungsinya untuk mendukung pelaksanaan desentralisasi.Kekhususan tersebut yaitu adanya suatu kewajiban mengintegrasikan nilai-nilai sosio kultural, menciptakan stabilitas dalam dinamika politik, ekonomi dan budaya, mengupayakan terwujudnya ketenteraman dan ketertiban wilayah sebagai perwujudan kesejahteraan rakyat serta masyarakat dalam kerangka membangun integritas kesatuan wilayah. 
Dalam hal ini, fungsi utama pemerintah kecamatan selain memberikan pelayanan kepada masyarakat, juga melakukan tugas-tugas pembinaan wilayah seperti disebutkan dalam Peraturan Pemerintah Nomor 19 Tahun 2008.Dari amanat peraturan pemerintah tersebut jelas bahwa kecamatan mempunyai kedudukan dan peranan yang sangat penting dalam rangka efektivitas penyelenggaraan pemerintahan daerah.Oleh karena itu pemerintah kecamatan harus dapat mempraktekkan prinsipprinsip good governance sesuai yang tertuang dalam Pasal 20 Undang-undang Nomor 32 Tahun 2004 Tentang Pemerintah Daerah.

Disebutkan bahwa dalam mengatur penyelenggaraan pemerintahan wajib menjalankan asasasas umum penyelenggaraan pemerintahan dalam Pasal 20 Undang-undang Nomor 32 Tahun 2004 Tentang Pemerintah Daerah diantaranya asas kepastian hukum, asas tertib penyelenggaraan pemerintahan, asas kepentingan umum, asas keterbukaan, asas proporsionalitas, asas profesionalitas, asas akuntabilitas, asas efisiensi dan efektivitas.

Asas-asas penyelenggaraan pemerintahan yang tertuang dalam Undang-Undang Pemerintah Daerah senada dengan karakteristik atau prinsip-prinsip good governance yang saling memperkuat dan tidak dapat berdiri sendiri antara lain adanya Participation (Partisipasi), Rule of Law (Kepastian Hukum), Tranparency (trasparansi), Responsiveness (responsivitas), Consensus Orientation (orientasi konsensus), Equity (keadilan), Efficiency and Effectivenes (Efesien dan Efektif), Accountability (akuntabilitas), Strategic Vision (visi strategis).

Dalam kedudukannya sebagai perangkat daerah, pemerintah kecamatan dalam pelaksanaan tugasnya menerima pelimpahan sebagian kewenangan dari bupati/walikota untuk menangani sebagian urusan otonomi daerah terutama yang bermakna urusan pelayanan masyarakat. Selain itu, pemerintah kecamatan juga mengemban menyelenggarakan tugas-tugas umum pemerintahan yang meliputi Mengkoordinasikan kegiatan pemberdayaan masyarakat; Mengkoordinasikan upaya penyelenggaraan ketenteraman dan ketertiban umum; Mengkoordinasikan penerapan dan penegakanperaturan perundang-undangan; mengkoordinasikan pemerliharaan prasarana dan fasilitas pelayanan umum; Mengkoordinasikan penyelenggaraan kegiatan pemerintahan di tingkat kecamatan; membina penyelenggaraan pemerintahan desa dan/atau kelurahan; dan Melaksanakan pelayanan masyarakat yang menjadi ruang lingkup tugasnya dan/atau yang belum dapat dilaksanakan pemerintahan desa atau kelurahan seperti tercantum dalam Undang-Undang Nomor 32 Tahun 2004 Tentang Pemerintah Daerah dan turut serta wajib menyelenggarakan pemerintahan berdasarkan asasasas penyelenggaraan pemerintahan sebagaimana yang telah disebutkan sebelumnya pada Pasal 20.

Kecamatan Gajah Putih merupakan salah satu kecamatan yang berada dalam wilayah Kabupaten Bener Meriah dan merupakan kecamatan paling muda dibandingkan dengan kecamatankecamatan lainnya di Kabupaten Bener Meriah. Berdasarkan hasil observasi peneliti prinsip-prinsip good governance di Kecamatan Gajah Putih masih belum di implementasikan secara efektif dan efisien sehingga berdampak pada pelayanan kepada masyarakat yang belum maksimal hal tersebut merupakan bentuk dari penyesuaian pelayanan karena sebagaimana diketahui Kecamatan Gajah Putih merupakan kecamatan yang baru saja terbentuk di tahun 2010.

Diketahui bahwa terdapat beberapa bentuk pelayanan yang diberikan oleh Kecamatan Gajah Putih kepada masyarakat diantaranya pembuatan akta jual beli (AJB), pendataan penerima bantuan langsung tunai dana desa (BLT-DD), penerapan sistem informasi (SID), pembuatan rekomendasi surat izin usaha perdagangan (SIUP), pembuatan izin mendirikan bangunan (IMB) dan gangguan (HO), serta penerbitan rekomendasi surat izin tempat usaha (SITU).

Berdasarkan hasil observasi awal peneliti dari keenam jenis pelayanan yang diberikan tersebut, pelayanan pembuatan akjta jual beli (AJB) tanah adalah yang masih terlihat belum efektif dan efisien. Pada tahun 2020 terdapat pembuatan 101 AJB tanah di Kantor Camat Gajah Putih, dan terdapat beberapa permasalahan dalam pemberian pelayanan pembuatan AJB tanah seperti masih 
kurangnya fasilitas pendukung untuk mencetak Akta Jual Beli tanah, masih adanya pungutan liar (pungli) diluar ketentuan yang dilakukan oleh oknum-oknum yang mengaku calo dari kantor camat, dan permasalahan camat yang terkendala izin Pejabat Pembuat Akte Tanah (PPAT) serta seringnya tertahan berkas-berkas pengajuan AJB tanah di tahap kantor desa, dan kantor camat yang tidak sesuai dengan Standar Operasional Prosedur (SOP) yang menjadi pedoman pemberian pelayanan pembuatan AJB tanah.

Berdasarkan fenomena tersebut peneliti mengambil topik permasalahan dalam penelitian ini terkait Implementasi Good Governance di Kecamatan Gajah Putih Kabupaten Bener Meriah tahun 2020 dengan studi kasus pada pelayanan pembuatan AJB tanah, karena diketahui pemberian pelayanan pembuatan AJB tanah kepada publik masih belum sesuai dengan penerapan prinsip dan harapan terselenggaranya tata kelola pemerintahan yang baik (Good Governance) yang efektif dan efisien.

\section{Rumusan Masalah}

1. Mengapa implementasi penyelenggaraan pemerintahan di Kecamatan Gajah Putih khususnya pada pelayanan pembuatan Akta Jual Beli tanah belum berjalan sesuai dengan prinsip-prinsip Good Governance?

Apa hambatan implementasi Good Governance di Kecamatan Gajah Putih Kabupaten Bener Meriah tahun 2020 khususnya pada pelayanan pembuatan Akta Jual Beli tanah

\section{Kajian Terdahulu: Landasan Teoritis}

Teori merupakan landasan yang teramat penting dalam memahami, menafsirkan dan memaknai data, oleh karena itu untuk memudahkan penafsiran data dalam penelitian ini, maka penulis menggunakan beberapa teori sebagai berikut:

\section{Good Governance}

Implementasi dari prinsip good governance adalah untuk memberikan mekanisme dan pedoman dalam memberikan keseimbangan bagi para stakeholders dalam memenuhi kepentingannya masing-masing. Dari berbagai hasil yang dikaji Lembaga Administrasi Negara (LAN) menyimpulkan ada sembilan aspek fundamental dalam perwujudan good governance, yaitu:

1. Participation (Partisipasi),

2. Rule of Law (Kepastian Hukum),

3. Tranparency (trasparansi),

4. Responsiveness (responsivitas),

5. Consensus Orientation (orientasi konsensus),

6. Equity (keadilan),

7. Efficiency and Effectivenes (Efesien dan Efektif),

8. Accountability (akuntabilitas),

9. Strategic Vision (visi strategis),

Negara dengan birokrasi pemerintahan dituntut untuk merubah pola pelayanan diri birokratis elitis menjadi birokrasi populis.Dimana sektor swasta sebagai pengelola sumber daya di luar negara dan birokrasi pemerintah pun harus memberikan konstribusi dalam usaha pengelolaan sumber daya yang ada.Penerapan cita good governance pada akhirnya mensyaratkan keterlibatan organisasi masyarakatan sebagai kekuatan penyeimbang Negara.

Bintoro Tjokromidjojo memandang Good Governance sebagai suatu bentuk manajemen 
pembagunan yang juga disebut administrasi pembangunan, yang menempatkan peran pemerintah sentral yang menjadi agen of change dari suatu masyarakat berkembang atau developing di dalam Negara berkembang.Pemerintah betindak sebagai regulator dan pelaku pasar untuk menciptakan iklim yang kondusif dan melakukan investasi prasarana yang mendukung dunia usaha.

Menurut Mardiasmo (2002:18) Good Governance adalah suatu konsep pendekatan yang berorientasi kepada pembangunan sektor publik oleh pemerintahan yang baik. Konsep good governance sendiri dalam beberapa tahun belakangan ini banyak dibicarakan dalam berbagai konteks dan menjadi isu yang mengemuka dalam pengelolaan pemerintahan.

Hal ini terjadi karena bagian dari luapan pola-pola lama dalam penyelenggaraan pemerintahan tidak sesuai lagi dengan tatanan masyarakat yang telah berubah atau dengan kata lain semakin tidak efektifnya pemerintahan disamping semakin berkembangnya kualitas demokrasi, hak asasi manusia dan partisipasi publik dalam pengambilan kebijakan. Beberapa pakar dan teoritisi administrasi berpendapat bahwa peranan pemerintah harus memfokuskan pada upaya meningkatkan pelayanan kepada masyarakat selain pemberdayaan dan pembangunan.Pemerintahan dijalankan berdasarkan kesepakatan-kesepakatan yang terbentuk melalui diskusi yang berlangsung dalam ruang publik.

Melalui paradigma good governance sebagai alternatif penyelenggaraan pemerintahan, potensi masing-masing stakeholders dapat diaktualisasikan dalam mengatasi berbagai permasalahan dan kendala yang dihadapi daerah dalam pelaksanaan otonomi daerah sebagaimana tertuang dalam Undang-Undang No. 32 Tahun 2004 tentang Pemerintahan Daerah, sehingga perlu dijamin perkembangan kreativitas dan aktivitas yang mengarah pada peningkatan kesejahteraan masyarakat, demokratisasi serta kemandirian daerah.

\section{Implementasi Kebijakan}

Implementasi kebijakan publik (Publik Policy Implementation) merupakan salah satu tahapan dari proses kebijakan publik. Implementasi kebijakan publik menurut Webster: "to provide the means for carrying out (menyediakan sarana untuk melaksanakan sesuatu); to give practical effect to" (menimbulkan dampak atau akibat terhadap sesuatu). Dari pengertian implementasi kebijakan menurut Webster ini dapat disimpulkan bahwa implementasi berarti menyediakan sarana untuk melaksanakan suatu kebijakan dan dapat menimbulkan dampak akibat terhadap sesuatu tertentu.

Menurut (Nugroho, 2003:158), implementasi kebijakan pada prinsipnya adalah cara agar sebuah kebijakan dapat mencapai tujuannya (tidak lebih dan tidak kurang). Selanjutnya (Nugroho, 2003:158) mengemukakan bahwa perencanaan atau sebuah kebijakan yang baik akan berperan menentukan hasil yang baik.

Implementasi kebijakan merupakan tahap yang krusial dalam proses kebijakan publik, suatu program kebijakan harus diimplementasikan agar mempunyai dampak atau tujuan yang dinginkan. Implementasi kebijakan dipandang dalam pengertian yang luas merupakan tahap dari proses kebijakan segera setelah penetapan undang-undang. Implementasi merupakan pelaksanaan undangundang yang didalamnya berbagai aktor, organisasi, prosedur, dan teknik bekerja bersama-sama untuk menjalankan kebijakan dalam upaya untuk meraih tujuan-tujuan kebijakan atau programprogram (Budi Winarno, 2014:147).

Model implementasi kebijakan yang berspektif top down dikembangkan oleh (Edwards III dalam Leo, 2008:149) yang menamakan implementasi kebijakan publik dengan Directy and indirect Impact on Implementation. Dalam pendekatan yang diimplementasikan oleh Edward III, terdapat empat variable yang sangat menentukan suatu kebijakan yaitu komunikasi, sumber daya, disposisi dan struktur birokrasi. 


\section{Pelayanan Publik}

Menurut Kotler (2008), pelayanan adalah setiap tindakan atau kegiatan yang dapat ditawarkan oleh suatu pihak kepada pihak lain, yang pada dasarnya tidak berwujud dan tidak mengakibatkan kepemilikan apapun.Sedangkan menurut Pasolong (2010:128), pelayanan pada dasarnya didefinisikan sebagai aktifitas seseorang, sekelompok dan/atau organisasi baik secara langsung maupun tidak langsung untuk memenuhi kebutuhan.Jadi dapat dikatakan bahwa dalam pelayanan terdapat dua aspek yaitu seseorang/organisasi dan pemenuhan kebutuhan.

Sesuai dengan Undang-Undang Nomor 25 Tahun 2009 tentang Pelayanan Publik adalah kegiatan atau rangkaian kegiatan dalam rangka pemenuhan kebutuhan pelayanan bagi setiap warga negara dan penduduk atas barang, jasa, dan/atau pelayanan administratif yang disediakan oleh penyelenggara pelayanan publik.

Berdasarkan Surat Keputusan Menteri Pendayagunaan Aparatur Negara No: 63/KEP/M.PAN/7/2003, pelayanan publik adalah segala kegiatan pelayanan yang dilaksanakan oleh penyelenggara pelayanan publik sebagai upaya pemenuhan kebutuhan penerima pelayanan maupun pelaksanaan ketentuan peraturan perundang-undangan. Menteri Pendayagunaan Aparatur Negara dalam keputusan Nomor 63 tahun 2003 tentang Pedoman Umum Penyelenggaraan Pelayanan Publik menyatakan bahwa "hakikat layanan publik adalah pemberian layanan prima kepada masyarakat yang merupakan perwujudan dari kewajiban aparatur pemerintah sebagai abdi masyarakat”. Pernyataan ini menegaskan bahwa pemerintah melalui instansi-instansi penyedia layanan publik, mereka bertanggung jawab memberikan layanan prima kepada masyarakat. Dengan demikian pelayanan publik adalah pemenuhan keinginan dan kebutuhan masyarakat oleh penyelenggara negara.

\section{Metodologi Penelitian}

Penelitian ini menggunakan penelitian kualitatif dengan pendekatan deskriptif analisis, karena persoalannya sangat komprehensif, mendalam dan sangat luas.Pengumpulan data dilakukan dengan observasi, wawancara dan dokumentasi.

\section{Hasil Penelitian}

hasil penelitian diketahui permasalahan yang terjadi pada pelayanan pembutan AJB tanah di Kecamatan Gajah Puth yang belum sesuai dengan penerapan prinsip good governance yaitu efektif dan efisien pada pelaksanaannya antara lain:

1. Kurangnya fasilitas pendukung untuk mencetak Akta Jual Beli tanah

2. Masih adanya pungutan liar (pungli) diluar ketentuan yang dilakukan oleh oknum-oknum yang mengaku calo dari kantor camat.

3. Camat yang terkendala izin Pejabat Pembuat Akte Tanah (PPAT)

4. Seringnya tertahan berkas-berkas pengajuan AJB tanah di tahap kantor desa, dan kantor camat yang tidak sesuai dengan Standar Operasional Prosedur (SOP)

Keempat hal tersebut jika dikaitkan dengan teori implementasi kebijakan menurut Edward III maka ditemukan kesesuaian dengan indikator Sumber daya, Disposisi, dan Struktur Birokrasi.Dalam konsep good governance, prinsip efisiensi dan efektivitas mempunyai makna bahwa proses-proses dan lembaga-lembaga menghasilkan sesuai dengan apa yang telah digariskan dengan menggunakan sumber-sumber yang tersedia sebaik mungkin.

Suatu program atau kegiatan dikatakan efektif apabila mencapai tujuan dan sasaran akhir 
programdengan kata lain pengujian dasar dari efektivitas adalah apakah program atau kegiatan menghasilkan hasil dan dampak yang diharapkan. Sedangkankonsep efisiensi menggambarkan rasio output yang dihasilkan terhadap input yang digunakan; atau dengan kata lain apakah input yang digunakan telah menghasilkan hasil sebanding dengan output program atau kebijakannya.

Suatu kebijakan, program atau kegiatan dinyatakan efektif efisien jika suatu target tertentu dapat dicapai dengan penggunaan sumber-sumber daya dan dana yang serendah-rendahnya diperbandingkan secara relatif terhadap kinerja usaha sejenis atau antar kurun waktu (Dwiyanto dkk, 2002).

Sebagaimana yang telah di rumuskan dalam undang-undang nomor 11 tahun 2006 tentang Pemerintahan Aceh, yang menjadikan Good Governance sebagai konsep pemerintahan. Pada pasal 1 ayat 18 menyatakan Kecamatan adalah suatu wilayah kerja camat sebagai perangkat daerah kabupaten/kota dalam penyelenggaraan pemerintahan kecamatan.Yang kemudian di perkuat lagi oleh pasal 14 ayat 1 .

Pembagian dan pelaksanaan urusan pemerintahan, baik pada Pemerintahan di Aceh maupun pemerintahan di kabupaten/ kota dilakukan berdasarkan kriteria eksternalitas akuntabilitas, dan efisiensi dengan memperhatikan keserasian hubungan antar pemerintahan di Aceh. Penyelenggaraan Pemerintahan Aceh dan pemerintahan kabupaten/kota berpedoman pada azas umum dalam penyelenggaraan pemerintahan yang di tuangkan pada pasal Undang-Undang nomor 11 tahun 2006 tentang Pemerintahan Aceh.Asas umum penyelenggaraan pemerintahan yang terdiri atas azas keislaman, azas kepastian hukum, azas kepentingan umum, azas tertib penyelenggaran pemerintaham azas keterbukaan, azas proporsionalitas, azas profesionalitas, azas akuntabilitas, azas efektivitas dan efisiensi.

Berikut adalah analisis peneliti terkait permasalahan Implementasi Good Governance di Kecamatan Gajah Putih Kabupaten Bener Meriah tahun 2020 dengan studi kasus pada pelayanan pembuatan AJB tanah dengan menggunakan grand teori implementasi kebijakan menurut Edward III dengan kesesuaian indikator sumber daya, disposisi dan struktur birokrasi. Penelitian memfokuskan penerapan prinsip good governance hanya pada prinsip efektif dan efisien.

Berdasarkan hasil penelitian tentang Implementasi Good governance di Kecamatan Gajah Putih Kabupaten Bener Meriah tahun 2020 dengan studi kasus pada pelayanan pembuatan AJB tanah menunjukkan bahwa belum efektif dan efisien pelayanan pembuatan AJB tanah disebabkan oleh sumberdaya manusia yaitu camat yang belum memiliki izin PPAT sementara pada tahun 2020 sehingga tidak dapat menerbitkan AJB tanah dan mengakibatkan penumpukan berkas pengurusan AJB tanah milik masyarakat terlalu lama, serta sumberdaya fasilitas yaitu belum dimilikinya printer khusus untuk mencetak AJB tanah di Kecamatan Gajah Putih, dan mengakibatkan untuk mencetak AJB tanah diharuskan melakukan pencetakan ditempat lain.

Peneliti menggabungkan indikator disposisi dan struktur birokrasi disebabkan karena adanya keterkaitan antara satu dengan lainnya dalam implementasi prinsip good governance yaitu efektivitas dan efisiensi dalam pelayanan pembuatan AJB tanah.

Berdasarkan hasil penelitian yang termasuk permasalahan yang menjadikan pelayanan pembuatan AJB tanah belum efektif dan efisien sesuai prinsip tata kelola pemerintahan yang baik (good governance) disebabkan karena komitmen para pemberi layanan yang masih belum maksimal, terutama belum tersedianya SOP khusus pelayanan pembuatan AJB tanah.

Diketahui belum tersedianya SOP dikarenakan Kecamatan Gajah Putih merupakan salah satu kecamatan yang baru saja terbentuk di Kabupaten Bener Meriah, kurang lebih baru 10 tahun dibentuk, sehingga tata kelola pemerintahan kecamatan baik administrasi maupun sarana dan prasarana masih sangat terbatas ketersediaannya.

Tidak adanya SOP pelayanan pembuatan AJB tanah memunculkan permasalahan berikutnya, 
berdasarkan hasil penelitian menunjukkan bahwa dengan tidak tersedianya SOP pembuatan AJB tanah, menjadikan munculnya pihak-pihak yang menjadi calo dan melakukan pemungutan liar biaya tambahan pada transaksi pembuatan AJB tanah. Pungutan liar yang terjadi di Kecamatan Gajah Putih bukan hanya karena pemberian tawaran berupa imbalan jika menyelesaikan AJB tanah secara lebih cepat, namun juga terjadi atas biaya honorarium (jasa pembuatan) AJB tanah kepada masyarakat.

Pada pasal 32 ayat (1) Peraturan Pemerintah Nomor 24 Tahun 2016 Tentang PPAT disebutkan bahwa uang jasa (honorarium) PPAT dan PPAT sementara termasuk uang jasa (honorarium) saksi tidak boleh melebihi (satu persen) dari harga transaksi yang tercantum dalam akta. Namun yang terjadi di Kecamatan Gajah Putih karena tidak rincinya permasalahan biaya disebutkan dalam SOP yang juga belum tersedia adalah permintaan honorarium mencapai 1\% - 5\% kepada masyarakat dan hal ini termasuk dalam kategori pungutan liar (pungli).

Selain permasalahan biaya, akibat belum adanya SOP juga menjadikan tidak jelasnya waktu pembuatan AJB tanah.Jika dibandingkan dengan pelayanan pembuatan AJB tanah di Kecamatan Timang Gajah yang juga berada di Kabupaten Bener Meriah, pembuatan AJB tanah hanya membutuhkan waktu maksimal 3 hari kerja.Sedangkan yang terjadi di Kecamatan Gajah Putih adalah mencapai 1-2 minggu penyelesaian.

Tidak selesainya secara tepat waktu pembuatan AJB tanah selain disebabkan oleh belum terjabarkan secara rinci pada SOP, juga disebabkan oleh tingkah laku/watak (disposisi) para pelaksana yang dimulai dari unsur Kampung sampai pada unsur Kecamatan yang masih sering menunda-nunda penyelesaian berkas pengajuan pembuatan AJB tanah, seringnya berkas menumpuk ditingkatan Kampung dan Kecamatan, menjadikan masyarakat menunggu terlalu lama untuk mendapatkan AJB tanah. Hal ini menunjukkan bahwa fragmentasi para pelaksana pembuatan AJB tanah belum sesuai dengan prinsip good governance dengan azasnya yang memberikan pelayanan secara efektif dan efisien.

Upaya mewujudkan sistem pemerintahan yang efektif dan efisien dengan melaksanakan tugas pemerintahan yang baik (good governance) mencakup aspek administrasi. SOP merupakan pedoman bagi para pelaksana dalam menjalankan administrasi pemerintahan agar dapat mencapai pelayanan yang maskimal, dengan tidak dimilikinya SOP dalam pembuatan AJB tanah di Kecamatan Gajah Putih pada tahun 2020 menunjukkan bahwa para pelaksana dalam pembuatan AJB tanah masih belum menunjukkan komitmennya dalam rangka mewujudkan tata kelola pemerintahan sesuai dengan prinsip good governance.

Pelayanan pembuatan AJB tanah di Kecamatan Gajah Putih masih mengalami hambatanhambatan yang datang dari pihak internal maupun eksternal.Sebagaimana diketahui Kecamatan Gajah Putih baru saja dibentuk pada tahun 2010, keberadaannya kurang lebih baru sekitar 10 tahun. Proses administrasi dan ketersediaan fasilitas juga masih dalam proses penyesuaian dan pembenahan sebagai Kecamatan yang baru saja terbentuk.

Tata kelola pemerintahan atau good governance secara umum menyangkut pengelolaan dan penyelenggaraan pemerintahan yang baik. Tata kelola pemerintahan dapat ditinjau dari segi fungsional maupun pemerintah, Dari segi fungsional, yaitu dari segi aspek governance, yaitu apakah pemerintah telah berfungsi secara efektif dan efisien dalam upaya mencapai tujuan yang telah digariskan, atau justru sebaliknya dimana pemerintahan tidak berfungsi secara efektif dan terjadi inefisiensi

Pada hasil penelitian telah dijabarkan bahwa hambatan yang disebabkan oleh pihak internal adalah mengenai sumber daya manusia, sumber daya fasilitas dan SOP pelayanan pembuatan AJB yang belum tersedia.Dalam analisis teori implementasi kebijakan menurut Edward III, sumber daya manusia dan sumber daya fasilitas masuk kepada indikator sumber-sumber.Sedangkan SOP masuk pada indikator disposisi dan struktur birokrasi. 
Agar penyelenggaraan pemerintahan kecamatan dalam memberikan pelayanan kepada masyarakat demi memenuhi azas-azas efektifitas dan efesiensi sebagaimana prinsip dalam tata kelola pemerintahan yang baik (good governance) maka pihak pelaksana di kecamatan harus memiliki skala prioritas dalam memberikan pelayanan sesuai dengan sumber daya yang dimiliki oleh kecamatan.Selain itu pihak kecamatan juga harus segera membuat SOP pelayanan sehingga dalam memberikan pelayanan kepada masyarakat dapat lebih efektif dan efisien.

Aspek good governance dapat ditinjau dari apakah pemerintah telah berfungsi secara efektif dan efisien dalam upaya mencapai tujuan yang telah digariskan atau justru sebaliknya dimana pemerintahan tidak berfungsi secara efektif dan terjadi inefisiensi.Hal utama yang perlu diperhatikan yakni terkait seberapa besar komitmen penyelenggara pemerintahan mengaplikasikan konsep, prinsip, nilai-nilai dari good governance tersebut.Salah satu contoh implementasi good governance yakni pemerintahan yang mampu memberikan kemudahan, kepastian, dan bersih dalam memberikan pelayanan demi kesejahteraan masyarakat. Dalam hal penelitian yang dilakukan di Kecamatan Gajah Putih pada tahun 2020 masih belum tercapainya kemudahan, kepastian dan transparan sehingga menjadi tidak efektif dan efisien dalam membuat AJB tanah baik karena sumber daya maupun kepastian SOP yang belum dimiliki.

Pada hasil penelitian telah dipaparkan pula hambatan yang disebabkan pihak eksternal yaitu waktu pengukuran tanah mengalami hambatan karena lokasi pengukuran tanah sangat jauh, dan cenderung berada pada lokasi yang curam, sehingga menghabiskan waktu para aparatur kampung yang melakukan pengukuran tanah, tidak adanya Reje (Kepala Kampung/Desa) di kampung yang mengakibatkan berkas tertahan lama di desa, serta indikasi merubah ukuran tanah untuk menurunkan biaya yang timbul dari harga transaksi tanah pada pembuatan AJB tanah.

Hambatan dari eksternal muncul dari tingkatan pemerintahan desa.Salah satu aspek good governance adalah pengambilan keputusan dalam penyusunan kebijakan, apabila seorang pejabat pemerintah dalam mengambil sebuah keputusan guna melaksanakan pembangunan, terlebih dahulu perlu menerapkan prinsip-prinsip penyelenggaraan pemerintahan yang baik.Keputusan yang diambil harus berdasarkan kewenangan yang diberikan undang-undang mau pun yang dilimpahkan oleh pejabat.Keputusan tersebut harus diambil secara demokratis, transparan, akuntabilitas, dan benar.Tak terkecuali pada tingkat Pemerintahan Desa, dimana desa merupakan tingkat pemerintahan terendah yang justru bersinggungan langsung dengan masyarakat.Pemerintah Desa harus mampu hadir ditengah-tengah masyarakat sebagai wakil dari pemerintah.Oleh karenanya good governance dalam pemerintahan desa sangatlah penting.

\section{Kesimpulan}

Berdasarakan hasil penelitian tersebut di atas, maka dapat disimpulkan sebagai berikut:

1. Implementasi penyelenggaraan pemerintahan di Kecamatan Gajah Putih khususnya pada pelayanan pembuatan AJB tanah belum berjalan sesuai dengan prinsip good governance dengan azas efektif dan efisien.

2. Pada tahun 2020 Camat Kecamatan Gajah Putih baru saja dilakukan pergantian sehingga masih belum dapat menerbitkan AJB tanah karena belum terbitnya izin PPAT Sementara.

3. Tidak tersedianya printer khusus untuk mencetak AJB tanah di Kecamatan Gajah Putih sehingga untuk menerbitkan AJB tanah harus dilakukan pencetakan ditempat lainnya.

4. Kecamatan Gajah Putih tidak memiliki Standar Operasional Prosedur (SOP) pelayanan pembuatan AJB tanah sehingga menimbulkan indikasi pungutan liar karena tidak jelasnya biaya yang timbul atas transaksi akta dan membuat penyelesaian AJB tanah tidak tepat waktu karena tidak ada penyebutan batas hari maksimal pengerjaan AJB tanah tersebut. 
5. Hambatan internal pada pelayanan pembuatan AJB tanah di Kecamatan Gajah Putih antara lain sumber daya manusia, sumber daya fasilitas dan SOP yang belum tersedia.

6. Hambatan eksternal pada pelayanan pembuatan AJB tanah di Kecamatan Gajah Putih antara lain waktu pengukuran tanah mengalami hambatan karena lokasi pengukuran tanah sangat jauh, dan cenderung berada pada lokasi yang curam, sehingga menghabiskan waktu para aparatur kampung yang melakukan pengukuran tanah, Reje tidak berada di Kampung dan indikasi merubah ukuran tanah untuk menurunkan biaya yang timbul dari harga transaksi tanah pada pembuatan AJB tanah.

\section{Daftar Pustaka}

Dwiyanto, 2005.Mewujudkan Good Governance Melalui Pelayanan Publik. Yogyakarta: Gajahmada Universiti Press.

Kotler, Philip. 2008. Manajemen Pemasaran Edisi 12 Jilid 2. Jakarta: Indeks

Pasolong, Harbani. 2010. Teori Administrasi Publik, Bandung: Alfabeta.

Agustino, Leo. 2008. Dasar-dasar Kebijakan Publik. Bandung: Alfabeta

Budi Winarno. 2014. Kebijakan Publik; Teori, Proses, dan Studi Kasus. Yogyakarta: CAPS.

Mardiasmo. 2002. Akuntansi Sektor Publik. Yogyakarta: Penerbit Andi.

Nugroho, Riant. 2003 Kebijakan Publik Formulasi, Implementasi Dan Evaluasi. Jakarta: PT. Elex Media Komputindo.

Widodo, Joko. 2008. Analisis Kebijakan Publik. Jakarta. Bayumedia

Winarni, Budi. 2007. Teori Kebijakan Publik dan Proses Edisi Revisi. Yokyakarta: Media Presido

Qanun Kota Lhokseumawe Nomor 09 Tahun 2015 Tentang Pengelolaan Sampah 